\title{
Synthesis and Evaluation of 15-(4-(2-
}

\section{[18F]Fluoroethoxy)phenyl)pentadecanoic Acid: a Potential PET Tracer for Studying Myocardial Fatty Acid Metabolism}

\author{
Zhude Tu†, Shihong Li†, Terry L. Sharp ${ }^{\dagger}$, Pilar Herrero ${ }^{\dagger}$, Carmen S. Dence ${ }^{\dagger}$, Robert J. \\ Gropler ${ }^{\dagger}$, and Robert H. Mach ${ }^{\dagger}$, \\ tDivision of Radiological Sciences, Washington University School of Medicine, 510 South \\ Kingshighway Blvd. St. Louis, MO 63110, USA
}

\begin{abstract}
15-(4- $\left(2-\left[{ }^{18} \mathrm{~F}\right]\right.$ fluoroethoxy $)$ phenyl $)$ pentadecanoic acid $\left(\left[{ }^{18} \mathrm{~F}\right] 7\right)$ was synthesized as a PET probe for assessing myocardial fatty acid metabolism. The radiosynthesis of $\left[{ }^{18} \mathrm{~F}\right] 7$ was accomplished using a two step reaction, starting with the corresponding tosylate ester, methyl 15-(4-(2(tosyloxy)ethoxy)phenyl)pentadecanoate (5) and gave the radiolabeled fatty acid, $\left[{ }^{18} \mathrm{~F}\right] 7$ in a radiolabeling yield of $55-60 \%$ and a specific activity of $>2,000 \mathrm{Ci} / \mathrm{mmol}$ (decay corrected to EOB). The biological evaluation of $\left[{ }^{18} \mathrm{~F}\right] 7$ in rats displayed high uptake in heart $(1.94 \%$.ID/g at 5 min), which was higher than the uptake (\% ID/g) in blood, lung, muscle, pancreas and brain. MicroPET studies of $\left[{ }^{18} \mathrm{~F}\right] 7$ in Sprague-Dawley rats demonstrated excellent images of the myocardium when compared with $\left[{ }^{11} \mathrm{C}\right]$ palmitate images in the same animal. Moreover, the tracer kinetics of $\left[{ }^{18} \mathrm{~F}\right] 7$ paralleled those seen with $\left[{ }^{11} \mathrm{C}\right]$ palmitate, with an early peak followed by biphasic washout. When compared to $\left[{ }^{11} \mathrm{C}\right]$ palmitate, $\left[{ }^{18} \mathrm{~F}\right] 7$ exhibited a slower early clearance $(0.17 \pm 0.01$ vs. $0.30 \pm 0.02, \mathrm{P}<0.0001)$ and a significantly higher late clearance $(0.0030 \pm 0.0005$ vs. $0.0006 \pm 0.00013, \mathrm{P}<0.01)$. These initial studies suggest that $\left[{ }^{18} \mathrm{~F}\right] 7$ could be a potentially useful clinical PET tracer to assess abnormal myocardial fatty acid metabolism.
\end{abstract}

\section{Keywords}

Fatty acid; PET imaging; F-18

\section{INTRODUCTION}

Fatty acid metabolism is the major source of energy production in the normal myocardium contributing $90 \%$ of aerobic metabolism through the $\beta$-oxidation pathway (1-3).

Abnormalities in myocardial fatty acid metabolism play a central role in a variety of cardiac diseases such as obesity, diabetes mellitus, dilated cardiomyopathy and myocardial ischemia $(1,4)$. An overdependence on fatty acid metabolism typifies obesity and diabetes mellitus. This increase in fatty acid use can initiate a cascade of events such as worsening myocardial insulin resistance, impaired energetics, an increase in oxidative stress and lipid accumulation, all of which have detrimental effects on myocellular health and can lead to reduced cardiac function (5-7). In contrast, a reduction in fatty acid metabolism leading to an overdependence on glucose use occurs in left ventricular hypertrophy, dilated cardiomyopathy and myocardial ischemia. This metabolic pattern can impair cardiac

*Address correspondence to: Robert H. Mach, Ph.D. Division of Radiological Sciences Washington University School of Medicine Campus Box 8225510 S. Kingshighway Blvd. St. Louis, MO 63110 Tel: 314-362-8538, Fax: 314-362-8555 rhmach@ mir.wustl.edu. 
function through a variety mechanisms including reduced energy production, increased oxidative stress and accelerated cell death $(8,9)$. The importance of altered fatty acid metabolism in these various cardiac disease processes is highlighted by the robust development of new therapeutics designed to favorably manipulate myocardial fatty acid use such as the peroxisome proliferator-activated receptor alpha (PPAR $\alpha$ ) agents and partial fatty acid oxidation inhibitors (10-12).

Detection of these different patterns in myocardial fatty acid metabolism may have important diagnostic, prognostic and therapeutic implications in the management of the cardiac patient. However, to achieve this goal requires the availability of an accurate and widely applicable noninvasive method to image myocardial fatty acid metabolism. To this end, investigators have focused on optimizing the structures of the fatty acids to identify radioligands that have extended retention time in heart and suitable pharmacokinetic properties for use as positron emission tomography (PET) or single photon emission computed tomography (SPECT) imaging probes (Figure 1) (13-16). However, because PET has higher sensitivity and higher spatial and temporal resolution compared to SPECT, developing a suitable PET probe which is capable of accurately quantifying myocardial fatty acid metabolism is highly desirable. Currently, $\left[{ }^{11} \mathrm{C}\right]$ palmitate (Figure 1) is the most accurate PET radiotracer for measuring myocardial fatty acid metabolism. However, the short half-life of carbon-11 $\left(\mathrm{t}_{1 / 2}=20 \mathrm{~min}\right)$ limits the use of $\left[{ }^{11} \mathrm{C}\right]$ palmitate in the study of cardiovascular disease to imaging centers having the capability to produce the radiotracer onsite. Therefore, a number of groups have focused on developing fluorine-18 labeled PET tracers which are capable of imaging fatty acid uptake in the heart.

In this regard, two different strategies have been pursued: 1) developing radiotracers such as $\left[{ }^{11} \mathrm{C}\right]$ palmitate whose kinetics closely track unlabeled fatty acids and thus reflect all aspects of myocardial fatty acid oxidation and storage (7,16-19); and, 2) developing radiolabeled tracers that will be trapped within the myocardium and can thus reflect a specific aspect of fatty acid metabolism such as cellular uptake $(16,20-28)$. For the first strategy, the advantages are the assessment of various aspects of myocardial fatty acid metabolism, such as uptake, oxidation and storage, with appropriate mathematical modeling techniques capable of quantifying fatty acid metabolism in each pathway. In contrast, trapped fatty acid tracers offer the potential of higher image quality, but are not capable of discriminating between the oxidation and storage pathways. A prime example of the latter approach is the radiotracer, 14-(R,S)-[ $\left[{ }^{18}\right.$ F $]$ fluoro-6-thia-heptadecanoic acid ( $\left[{ }^{18}\right.$ F $]$ FTHA) (Figure 1) $(20,21)$. Imaging studies of $\left[{ }^{18} \mathrm{~F}\right] \mathrm{FTHA}$ showed high uptake and retention in the myocardium in various diseases (23-25), but this radiotracer lacked sensitivity to measure the inhibition of $\beta$-oxidation by myocardium under conditions of hypoxia (14). Subsequently, 16-

$\left[{ }^{18} \mathrm{~F}\right]$ fluoro-4-thia-palmitate $\left(\left[{ }^{18} \mathrm{~F}\right] \mathrm{FTP}\right)$ (Figure 1 ) was developed and its metabolic trapping function was proportional to $\beta$-oxidation under normal oxygenation and hypoxic conditions (22). However, it is not clear if $\left[{ }^{18} \mathrm{~F}\right] \mathrm{FTP}$ can accurately differentiate between fatty acid oxidation and esterification (27).

Recently, trans-9-(RS)- $\left[{ }^{18} \mathrm{~F}\right]$ fluoro-3,4-(RS,RS) methyleneheptadecanoic acid ([ ${ }^{18}$ F]FCPHA) (Figure 1), which incorporates a cyclopropyl group at $\mathrm{C} 3-\mathrm{C} 4$ to block $\beta$ oxidation was reported as a radiolabeled fatty acid analogue (26). The uptake of $\left[{ }^{18} \mathrm{~F}\right] \mathrm{FCPHA}$ in rat myocardium reached approximately $1.5 \% \mathrm{ID} / \mathrm{gram}$ tissue at $5 \mathrm{~min}$ and displayed little change over a period of $60 \mathrm{~min}$. However, the impact of altered plasma substrate levels, cardiac workload and myocardial blood flow on the pharmacokinetics of $\left[{ }^{18} \mathrm{~F}\right] \mathrm{FCPHA}$ is not known. It is also not clear if the kinetics of $\left[{ }^{18} \mathrm{~F}\right] \mathrm{FCPHA}$ will be able to differentiate between fatty acid uptake, oxidation and esterification. Currently, both $\left[{ }^{18} \mathrm{~F}\right] \mathrm{FTP}$ and $\left[{ }^{18} \mathrm{~F}\right] \mathrm{FCPHA}$ are being evaluated in phase-1 clinical trials (4). In 2009, 17-[4(2-[ ${ }^{18}$ F]fluoroethyl)-1H-1,2,3-triazol-1-yl]-6-thia-heptadecanoic acid, a "click-labeling" 
analogue of $\left[{ }^{18}\right.$ F]FTHA, was reported as a potential PET agent for visualizing fatty acid metabolism in myocardium (28). However, the same issues apply to this radiotracer regarding the ability to differentiate between fatty acid oxidation and storage mechanisms in the heart.

The goal of our research was to identify an ${ }^{18} \mathrm{~F}$-labeled fatty acid analogue which is capable of mimicking $\left[{ }^{11} \mathrm{C}\right]$ palmitate with regard to its ability to measure fatty acid uptake, $\beta$ oxidation, and storage as triglycerides. The lead compound for our studies was 15-(paraiodophenyl)-pentadecanoic acid (IPPA) (Figure 1), which was developed over twenty years ago as a SPECT myocardial imaging agent. In this case, the $p$-iodine atom of IPPA was replaced with a 2-fluoroethoxy group to make 15-(4-(2-fluoroethoxy)phenyl)pentadecanoic acid (7) (Figure 1). IPPA was chosen as the lead compound for developing a PET radiotracer because its kinetics closely match those of $\left[{ }^{11} \mathrm{C}\right]$ palmitate but are too rapid to be imaged with clinical SPECT scanners.

In this article, we report the synthesis and radiosynthesis of $\left[{ }^{18} \mathrm{~F}\right] 7$, and our initial results measuring myocardial uptake in rats. MicroPET imaging studies of $\left[{ }^{18} \mathrm{~F}\right] 7$ were also performed in Sprague-Dawley rats and its pharmacokinetics were compared with that of $\left[{ }^{11} \mathrm{C}\right]$ palmitate.

\section{EXPERIMENTAL PROCEDURES}

\section{General Chemistry}

All analytical grade chemicals and reagents were purchased from Sigma-Aldrich (Milwaukee, WI) and were used without further purification unless otherwise specified. Flash column chromatography was conducted using Scientific Adsorbents, Inc. silica gel,

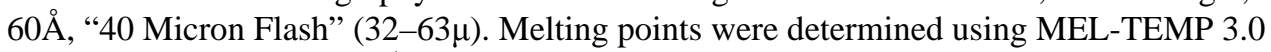
apparatus and uncorrected. ${ }^{1} \mathrm{H}$ NMR spectra were recorded at $300 \mathrm{MHz}$ on a Varian Mercury-VX spectrometer with $\mathrm{CDCl}_{3}$ as solvent and tetramethylsilane (TMS) as the internal standard. All chemical shift values are reported in ppm $(\delta)$. Elemental analyses $(\mathrm{C}$, H) were determined by Atlantic Microlab, Inc. (Norcross, GA).

\section{Methyl 15-bromopentadecanoate (2)}

A 2.0 M solution of trimethylsilyl diazomethane in hexane $(3.4 \mathrm{~mL}, 6.8 \mathrm{mmol})$ was added to the solution of 15-bromopentadecanoic acid $\mathbf{1}(1 \mathrm{~g}, 3 \mathrm{mmol})$ in THF/MeOH (v/v, 7/2) $(18$ $\mathrm{mL}$ ) and the reaction mixture was stirred at room temperature for $2 \mathrm{hr}$. The solvent was removed under reduced pressure. Chloroform $(80 \mathrm{~mL})$ was used to dissolve the residue and the solution was washed with water $(2 \times 30 \mathrm{~mL})$ and brine $(2 \times 30 \mathrm{~mL})$. The organic solution was dried over sodium sulfate. After the solvent was removed under reduced pressure, it afforded 2 as colorless syrup $(0.99 \mathrm{~g}, 99 \%) .{ }^{1} \mathrm{H}$ NMR $\left(300 \mathrm{MHz}, \mathrm{CDCl}_{3}\right): \delta 1.2$ - 1.36 (m, 20H); $1.36-1.48(2 \mathrm{H}, \mathrm{m}) ; 1.58-1.78(\mathrm{~m}, 2 \mathrm{H}) ; 1.79-1.92(\mathrm{~m}, 2 \mathrm{H}) ; 2.26-2.34$ $(\mathrm{t}, 2 \mathrm{H}) ; 3.36-3.48(\mathrm{t}, 2 \mathrm{H}) ; 3.67(\mathrm{~s}, 3 \mathrm{H})$.

\section{Methyl 15-(4-(benzyloxy)phenyl)pentadecanoate (3)}

A solution of compound 2 (400 mg, $1.2 \mathrm{mmol})$ in 2-methyl-2-butanol ( $5 \mathrm{~mL}$ ) was added to a round bottom flask $(25 \mathrm{~mL})$ that contained 4-benzyloxyphenylboronic acid methyl ester (408 mg, $1.79 \mathrm{mmol}), \mathrm{Pd}(\mathrm{OAc})_{2}(26.8 \mathrm{mg}, 12 \mathrm{mmol}),\left[\mathrm{HP}(\mathrm{t}-\mathrm{Bu})_{2} \mathrm{Me}_{\mathrm{BF}}\right.$ (62.7 mg, 0.25 $\mathrm{mmol})$, and potassium tert-butoxide (KO-t-Bu) $(53.5 \mathrm{mg}, 0.48 \mathrm{mmol})$, and the reaction mixture was stirred overnight at ambient temperature. The reaction was quenched with ethyl acetate $(60 \mathrm{~mL})$, water $(13 \mathrm{~mL})$ and glacial acetic acid $(2 \mathrm{~mL})$. The organic layer was separated and washed with brine $(3 \times 10 \mathrm{~mL})$. The organic solution was dried over sodium sulfate and the solvent was removed under reduced pressure. The product was purified by 
silica gel column chromatography using ethyl acetate/hexane $(1 / 10, v / v)$ as the eluent to afford the intermediate compound, 15-(4-(benzyloxy)phenyl)pentadecanoic acid, as a white solid (240 mg, 45\%), mp: $95-96^{\circ} \mathrm{C} .{ }^{1} \mathrm{H}$ NMR $\left(300 \mathrm{MHz}, \mathrm{CDCl}_{3}\right): \delta 1.38-1.18(\mathrm{~m}, 20 \mathrm{H})$, $1.70-1.50(\mathrm{~m}, 2 \mathrm{H}), 2.34(\mathrm{t}, 2 \mathrm{H}), 5.04(\mathrm{~s}, 2 \mathrm{H}), 2.54(\mathrm{t}, 2 \mathrm{H}), 6.93-6.87(\mathrm{~m}, 2 \mathrm{H}), 7.12-7.05$ $(\mathrm{m}, 2 \mathrm{H}), \delta 7.50-7.30(\mathrm{~m}, 5 \mathrm{H})$.

$0.5 \mathrm{~mL}$ of concentrated sulfuric acid was added into a solution of 15-(4(benzyloxy)phenyl)pentadecanoic acid $(230 \mathrm{mg}, 0.54 \mathrm{mmol})$ in $30 \mathrm{~mL}$ methanol. The reaction mixture was stirred at reflux overnight and quenched with a saturated aqueous solution of sodium bicarbonate. After removing the methanol under reduced pressure, the residue was partitioned between dichloromethane and brine. The organic layer was dried over sodium sulfate, filtered and concentrated under reduced pressure. The crude product was purified by silica gel column chromatography using ethyl acetate/hexane (v/v, 1/10) as the eluent to afford $3(185 \mathrm{mg}, 78 \%)$ as a white solid: $\mathrm{mp}: 56-57^{\circ} \mathrm{C} .{ }^{1} \mathrm{H}$ NMR $(300 \mathrm{MHz}$, $\left.\mathrm{CDCl}_{3}\right): \delta 1.18-1.40(\mathrm{~m}, 20 \mathrm{H}) ; 1.50-1.68(4 \mathrm{H}, \mathrm{m}) ; 2.26-2.36(\mathrm{t}, 2 \mathrm{H}) ; 2.48-2.58(\mathrm{t}, 2 \mathrm{H})$; $3.66(\mathrm{~s}, 3 \mathrm{H}) ; 5.04(\mathrm{~s}, 2 \mathrm{H}) ; 6.86-6.94(\mathrm{~m}, 2 \mathrm{H}) ; 7.06-7.13(\mathrm{~m}, 2 \mathrm{H}) ; 7.28-7.46(\mathrm{~m}, 5 \mathrm{H})$, elemental analysis: $\mathrm{C}_{29} \mathrm{H}_{42} \mathrm{O}_{3}$ Calcd: C: 79.41, H: 9.65; found: C: 79.14, H: 9.81 .

\section{Methyl 15-(4-hydroxyphenyl)pentadecanoate (4)}

Palladium (10 wt.\% on activated carbon; $50 \mathrm{mg}$ ) was added under a nitrogen atmosphere to a solution of compound $\mathbf{3}(185 \mathrm{mg}, 0.42 \mathrm{mmol})$ in ethyl acetate $(10 \mathrm{~mL})$. Hydrogen was added into the system to reach 6 pounds per square inch (psi) pressure and the mixture was stirred for over $5 \mathrm{hr}$. The reaction mixture was filtered through Celite and washed with ethyl acetate $(5 \mathrm{~mL})$. After removing excess solvent, the product was purified by silica gel column chromatography using ethyl acetate/hexane $(\mathrm{v} / \mathrm{v}, 1 / 5)$ as the eluent to afford $\mathbf{4}$ as a white solid (111 mg, 75\%): mp: $75-76^{\circ} \mathrm{C} .{ }^{1} \mathrm{H}$ NMR $\left(300 \mathrm{MHz}, \mathrm{CDCl}_{3}\right): \delta 1.30-1.47(\mathrm{~m}, 20 \mathrm{H})$; $1.50-1.68(\mathrm{~m}, 4 \mathrm{H}) ; 2.26-2.36(\mathrm{t}, 2 \mathrm{H}) ; 2.49-2.58(\mathrm{t}, 2 \mathrm{H}) ; 3.67(\mathrm{~s}, 3 \mathrm{H}) ; 6.72-6.78(\mathrm{~m}$, $2 \mathrm{H})$; 7.04-7.09 (m, 2H). Elemental analysis: $\mathrm{C}_{22} \mathrm{H}_{36} \mathrm{O}_{3}$ Calcd: C: $75.82, \mathrm{H}: 10.41$; found: $\mathrm{C}$ : 75.71, H: 10.46

\section{Methyl 15-(4-(2-(tosyloxy)ethoxy)phenyl)pentadecanoate (5)}

Compound 4 (106 mg, $0.30 \mathrm{mmol}$ ) and ethyleneglycol-1,2-bistosylate (338 mg, $0.91 \mathrm{mmol})$ were dissolved into anhydrous acetonitrile $(20 \mathrm{~mL})$, and then potassium carbonate $(42 \mathrm{mg}$, $0.30 \mathrm{mmol}$ ) was added into the reaction mixture. The reaction mixture was stirred at reflux under a nitrogen atmosphere for $18 \mathrm{hr}$ until thin layer chromatography (TLC) indicated the reaction was complete. After removing the solvent, dichloromethane $(10 \mathrm{~mL})$ was used to dissolve the residue. The organic layer was washed with brine $(10 \mathrm{ml})$, dried over sodium sulfate, filtered and concentrated under reduced pressure. The residue was purified by silica gel column chromatography using ether/hexane $(\mathrm{v} / \mathrm{v}, 1 / 2)$ as the eluent to afford compound 5 as a white solid $(145 \mathrm{mg}, 87 \%)$ : $\mathrm{mp}: 44-45^{\circ} \mathrm{C} .{ }^{1} \mathrm{H}$ NMR (300 $\left.\mathrm{MHz}, \mathrm{CDCl}_{3}\right): \delta 1.18-$ $1.40(\mathrm{~m}, 20 \mathrm{H}) ; 1.46-1.68(4 \mathrm{H}, \mathrm{m}) ; 2.26-2.36(\mathrm{t}, 2 \mathrm{H}) ; 2.45(\mathrm{~s}, 3 \mathrm{H}) ; 2.48-2.56(\mathrm{t}, 2 \mathrm{H})$; $3.66(\mathrm{~s}, 3 \mathrm{H}) ; 4.09-4.15(2 \mathrm{H}) ; 4.32-4.38 ; 6.66-6.74(\mathrm{~m}, 2 \mathrm{H}) ; 7.01-7.08(\mathrm{~m} 2 \mathrm{H}) ; 7.30-$ $7.37(\mathrm{~m}, 2 \mathrm{H}) ; 7.78-7.853(\mathrm{~m}, 2 \mathrm{H})$; Elemental analysis: $\mathrm{C}_{31} \mathrm{H}_{46} \mathrm{O}_{6} \mathrm{~S} \cdot 4 \mathrm{H}_{2} \mathrm{O}$ Calcd: C: 60.17 , H: 8.80 ; found: C: $60.03, \mathrm{H}: 8.44$

\section{Methyl 15-(4-(2-fluoroethoxy)phenyl)pentadecanoate (6)}

Compound 4 (104 mg, $0.3 \mathrm{mmol}$ ), 1-bromo-2-fluoroethane $(227 \mathrm{mg}, 1.8 \mathrm{mmol}$ ) and potassium carbonate $(246 \mathrm{mg}, 1.8 \mathrm{mmol})$ were added into a flask containing acetone (40 $\mathrm{mL}$ ). The reaction mixture was stirred at reflux under a nitrogen atmosphere for $18 \mathrm{hr}$. Volatiles were removed under reduced pressure, and the residue was partitioned between ethyl acetate $(60 \mathrm{~mL})$ and water $(20 \mathrm{~mL})$. The organic layer was washed with brine, dried over sodium sulfate, filtered and concentrated under reduced pressure. The residue was 
purified by silica gel column chromatography using ethyl acetate/hexane (v/v, 1/10) as the eluent to afford compound 6 as a white solid (115 mg, 98\%): $\mathrm{mp}: 66-67^{\circ} \mathrm{C}$. ${ }^{1} \mathrm{H}$ NMR (300 $\left.\mathrm{MHz}_{\mathrm{CDCl}}\right): \delta 1.18-1.40(\mathrm{~m}, 20 \mathrm{H}) ; 1.50-1.68(\mathrm{~m}, 4 \mathrm{H}) ; 2.26-2.37(\mathrm{t}, 2 \mathrm{H}) ; 2.49-2.58$ $(\mathrm{t}, 2 \mathrm{H}) ; 3.67(\mathrm{~s}, 3 \mathrm{H}) ; 4.12-4.18(\mathrm{t}, 1 \mathrm{H}), 4.22-4.27(\mathrm{t}, 3 \mathrm{H}) ; 4.64-4.70(\mathrm{t}, 1 \mathrm{H}) ; 4.80-4.85$ $(\mathrm{t}, 1 \mathrm{H}) ; 6.82-6.88(\mathrm{~m}, 2 \mathrm{H}) ; 7.06-7.13(\mathrm{~m}, 2 \mathrm{H})$. Elemental analysis: $\mathrm{C}_{24} \mathrm{H}_{39} \mathrm{FO}_{3} \mathrm{Calcd}: \mathrm{C}$ : 73.06, H: 9.96; found: C: $73.30, \mathrm{H}: 10.14$

\section{5-(4-(2-Fluoroethoxy)phenyl)pentadecanoic acid (7)}

Compound 6 (110 mg, $0.28 \mathrm{mmol})$ and $\mathrm{NaOH}(180 \mathrm{mg}$, $4.5 \mathrm{mmol})$ were dissolved into 11 $\mathrm{mL}$ of dichloromethane/methanol/water (5/5/1) and the reaction mixture was stirred at ambient temperature for $18 \mathrm{hr}$. Solvents were removed under reduced pressure, the residue was acidified to $\mathrm{pH} 2.0$ with $1 \mathrm{~N}$ aqueous $\mathrm{HCl}$ and extracted into ethyl acetate $(3 \times 20 \mathrm{~mL})$. The organic layer was dried over sodium sulfate, filtered, and concentrated under reduced pressure to afford compound 7 as a white solid ( $95 \mathrm{mg}, 89 \%$ ): $\mathrm{mp}: 84-85^{\circ} \mathrm{C} .{ }^{1} \mathrm{H}$ NMR (300 $\left.\mathrm{MHz}, \mathrm{CDCl}_{3}\right): \delta 1.18-1.40(\mathrm{~m}, 20 \mathrm{H}) ; 1.50-1.708(\mathrm{~m}, 4 \mathrm{H}) ; 2.30-2.39(\mathrm{t}, 2 \mathrm{H}) ; 2.49-2.58$ $(\mathrm{t}, 2 \mathrm{H}) ; 4.12-4.17(\mathrm{t}, 1 \mathrm{H}), 4.21-4.37$ (t, 3H); $4.64-4.70$ (t, 1H); $4.80-4.85(\mathrm{t}, 1 \mathrm{H}) ; 6.81-$ $6.88(\mathrm{~m}, 2 \mathrm{H}) ; 7.06-7.13(\mathrm{~m}, 2 \mathrm{H})$. Elemental analysis: $\mathrm{C}_{23} \mathrm{H}_{37} \mathrm{FO}_{3}$ Calcd: $\mathrm{C}: 75.29, \mathrm{H}: 9.80$; found: C: $72.77, \mathrm{H}: 9.82$.

\section{Radiochemistry}

Production of $\left[{ }^{18} \mathrm{~F}\right]$ Fluoride $-\mathrm{H}_{2}{ }^{18} \mathrm{O}$ was purchased from Rotem Industries (Israel). $\left[{ }^{18} \mathrm{~F}\right]$ Fluoride was produced in our institution by proton irradiation of enriched ${ }^{18} \mathrm{O}$ water (95\%) [reaction: ${ }^{18} \mathrm{O}(\mathrm{p}, \mathrm{n}){ }^{18} \mathrm{~F}$ ] using a Siemens Eclipse Cyclotron (Siemens Medical Systems, Inc, Knoxville, TN). ${ }^{18} \mathrm{~F}$-enriched $\mathrm{H}_{2}{ }^{18} \mathrm{O}$ (up to $1,500 \mathrm{mCi}$ ) was delivered from the Eclipse Cyclotron and transferred to the reaction vial through an anion-exchange column, Sep-Pak ${ }^{\circledR}$ Light QMA. $\left[{ }^{18} \mathrm{~F}\right]$ fluoride was eluted from the Sep-Pak by addition of an aqueous solution of potassium carbonate $\left(2 \mathrm{mg}\right.$ of $\mathrm{K}_{2} \mathrm{CO}_{3}$ in $0.5 \mathrm{~mL}$ of water) into the reactor vessel.

\section{5-(4-(2-[ $\left.{ }^{18} \mathrm{~F}\right]$ fluoroethoxy)phenyl)pentadecanoic acid $\left(\left[{ }^{18} \mathrm{~F}\right] 7\right)$}

$\left[{ }^{18} \mathrm{~F}\right]$ Fluoride $(100-150 \mathrm{mCi})$ was added to a $10-\mathrm{mL}$ Pyrex screw cap tube containing 5-6 $\mathrm{mg}$ of Kryptofix 2.2.2. and $1-2 \mathrm{mg}$ of $\mathrm{K}_{2} \mathrm{CO}_{3}$. HPLC grade acetonitrile $(3 \times 1.0 \mathrm{~mL})$ was used to remove the water by azeotropic evaporation from this reaction vessel at $110^{\circ} \mathrm{C}$ under a stream of nitrogen. After all the water was removed, a solution of precursor $11(1-2 \mathrm{mg})$ in $0.25-0.30 \mathrm{~mL}$ acetonitrile was added. The tube was caped and heated at $110-115^{\circ} \mathrm{C}$ for $5 \sim 10 \mathrm{~min}$. This solution was diluted with $1.0 \mathrm{~mL}$ acetonitrile and passed through a silica gel Sep-Pak (Alltech Associates, Inc, Deerfield, Ill) into a collection vial. An additional 2 $\mathrm{mL}$ of acetonitrile was used to rinse out the remaining radioactive product from the Sep-Pak into the above collection vial. Radio-thin-layer chromatography (radio-TLC) showed the radiochemical purity was $>95 \%$ on a Bioscan System 2000 system (Bioscan, Inc., Washington, DC). The acetonitrile was removed by a stream of nitrogen gas at $80-85^{\circ} \mathrm{C}$. $\left[{ }^{18} \mathrm{~F}\right] 6$ was used directly in the next step, without further purification. $0.5 \mathrm{~mL}$ of ethanol and $0.2 \mathrm{~mL}$ of a $2 \mathrm{~N} \mathrm{NaOH}$ aqueous solution were added into the above collection vessel containing dried $\left[{ }^{18} \mathrm{~F}\right] 6$. The vessel was heated at $80^{\circ} \mathrm{C}$ for $2 \mathrm{~min}$, and then $0.4 \mathrm{~mL}$ of $1 \mathrm{~N}$ aqueous $\mathrm{HCl}$ was added into the reaction mixture to neutralize the mixture to $\mathrm{pH}=7.0$. Acetonitrile $(2 \mathrm{~mL})$ was added and the reaction mixture was loaded through a $0.45 \mu \mathrm{m}$ filter into a high-performance liquid chromatography (HPLC) system equipped with an Alltech Econosil C18 reverse phase column $(10 \times 250 \mathrm{~mm})$ and eluted with acetonitrile/0.1 M ammonium formate buffer $(\mathrm{v} / \mathrm{v}, 85 / 15)$ at a flow rate of $4.0 \mathrm{ml} / \mathrm{min}$. A vial was used to collect the radioactive product from $24-25.5 \mathrm{~min}$. The HPLC mobile phase solution was concentrated under reduced pressure and the residue was azeotroped with ethanol $(2 \times 1$ 
$\mathrm{mL}$ ) to remove the residual mobile phase. The labeled fatty acid $\left[{ }^{18} \mathrm{~F}\right] 7$ was formulated in 6 $\mathrm{mL}$ of $3 \%$ human serum albumin (HSA) pre-incubated at $45^{\circ} \mathrm{C}$ for $3 \mathrm{~min}$ and passed through $0.22 \mu \mathrm{m}$ Millex-GP sterile syringe filter (cat\#: SLMP025SS, Millipore, Billerica, MA) into a final dose vial. The dose sample was authenticated by co-injection with the corresponding cold standard onto an analytical HPLC system which included an Alltech Econosil C18 column $(10 \mu \mathrm{m}, 250 \mathrm{~mm} \times 4.6 \mathrm{~mm})$, using acetonitrile: $0.1 \mathrm{M}$ ammonium formate buffer (v/ $\mathrm{v}, 90 / 10$ ) as mobile phase, $1.5 \mathrm{~mL} / \mathrm{min}$ flow rate, and $274 \mathrm{~nm}$ UV wavelength. Under these conditions, the retention time of the product $\left[{ }^{18} \mathrm{~F}\right] 7$ was $7.4 \mathrm{~min}$. The total radiosynthesis took $\sim 2 \mathrm{hr}$, the labeling yield ranged from $50-60 \%$ (decay corrected to EOB), radiochemical purity $>95 \%$, and specific activity $>2,000 \mathrm{Ci} / \mathrm{mmol}$ (decay correct to EOB).

\section{Biodistribution Studies}

All animal experiments were conducted in compliance with the NIH Guidelines for the Care and Use of Research Animals under IACUC approved protocols reviewed by the Washington University School of Medicine Animal Studies Committee. The biodistribution of $\left[{ }^{18} \mathrm{~F}\right] 7$ was performed in adult male Sprague-Dawley rats (170-250 g). Rats were anesthetized with $2-3 \%$ isoflurane $/ \mathrm{O}_{2}$ and $\left[{ }^{18} \mathrm{~F}\right] 7$ (approximately $20-25 \mu \mathrm{Ci} / 100 \mu \mathrm{L}$ ) was injected via the lateral tail vein. Rats were euthanized under anesthesia at 5, 30, 60 and 120 min post injection, 4-8 rats for each time point. Samples of blood, lung, liver, kidney, spleen, muscle, heart, brain, and pancreas were removed from each rat, weighed, and counted in a Beckman Gamma 8000 counter. Bone and fat were taken only for the 5 and 60 min time points from 4 rats. A standard dilution of the injectate was counted with the samples from each animal. The biodistribution results were calculated as percent injected dose per gram of tissue $(\% \mathrm{ID} / \mathrm{g})$ and are presented in Table 1.

\section{MicroPET Studies}

MicroPET imaging studies were performed in fasted male Sprague-Dawley rats using a microPET Focus 220 scanner. The rats were secured using a custom-designed acrylic restraining device, and placed inside the field of the window of the microPET Focus 220 scanner $(29,30)$. After a bolus injection of radiotracer via the right jugular catheter, microPET imaging studies of each rat were performed using a $1 \mathrm{hr}$ dynamic data acquisition. The microPET studies were first conducted with $\left[{ }^{11} \mathrm{C}\right]$ palmitate $(0.30-0.40 \mathrm{mCi} / 150 \mu \mathrm{L})$. After a $1 \mathrm{hr}$ period for biological clearance and radioactive decay, $\left[{ }^{18} \mathrm{~F}\right] 7(0.30-0.40 \mathrm{mCi} /$ $150 \mu \mathrm{L}$ ) was administered into the same rat and a second microPET dynamic imaging scan was acquired. $\left[{ }^{11} \mathrm{C}\right]$ palmitate and $\left[{ }^{18} \mathrm{~F}\right] 7$ blood time-activity curves were generated from dynamic PET images by placing one $3 \times 3$ voxel region of interest $(\mathrm{ROI})$ on the left ventricle. Myocardial ROIs encompassing the anterio-lateral myocardium were drawn on three consecutive PET slices as shown in Figure 2C and 2D.

\section{RESULTS AND DISCUSSION}

\section{Chemistry}

The synthesis of compound $\mathbf{7}$ is shown in Scheme 1. The ester $\mathbf{2}$ was made via O-alkylation of 15-bromopentadecanoic acid, $\mathbf{1}$ with trimethylsilyl diazomethane in tetrahydrofuran as described in the literature (31). The Suzuki cross-coupling of 2 with 4benzyloxyphenyboronic acid gave 15-(4-(benzyloxy)phenyl)pentadecanoic acid in modest yield (45\%). The methyl group was removed from the ester 3 because potassium tertbutoxide (KO-t-Bu) is a strong Lewis base that led to the hydrolysis of intermediate ester, methyl 15-(4-(benzyloxy)phenyl)pentadecanoate. It is of interest to note that when the Suzuki cross-coupling reaction was directly performed between 15 -bromopentadecanoic acid and 4-benzyloxyphenyboronic acid, no product was obtained. Esterification of 15-(4(benzyloxy)phenyl)pentadecanoic acid in methanol with concentrated sulfuric acid as a 
catalyst afforded compound $\mathbf{3}$ in 78\% yield. Removal of the benzyl group of $\mathbf{3}$ was accomplished by hydrogenolysis over 10\% palladium-activated carbon to afford 4 in $75 \%$ yield. O-alkylation of the phenol group of $\mathbf{4}$ with 1-bromo-2-fluoroethane in acetone using potassium carbonate as the base afforded the fluoroethoxy ester $\mathbf{6}$ in high yield (98\%). Hydrolysis of the ester group afforded the target compound $\mathbf{7}$ in $89 \%$ yield. Compound $\mathbf{5}$, the precursor for making $\left[{ }^{\mathbf{1 8}} \mathbf{F}\right] \mathbf{7}$, was prepared via O-alkylation of $\mathbf{4}$ with ethyleneglycol-1,2-bistosylate in acetonitrile using potassium carbonate as the base ( $87 \%$ yield) as shown in Scheme 1.

\section{Radiochemistry}

The radiosynthesis of the target compound $\left[{ }^{18} \mathrm{~F}\right] 7$ was made using the two step reaction sequence shown in Scheme 2. First, nucleophilic displacement of the tosylate group of ester 5 with $\left[{ }^{18} \mathrm{~F}\right] \mathrm{KF} /$ Kryptofix 2.2.2. in acetonitrile afforded $\left[{ }^{18} \mathrm{~F}\right] \mathbf{6}$. Hydrolysis of the ester with aqueous sodium hydroxide followed by neutralization with aqueous hydrochloric acid and semi-preparative HPLC gave the target fatty acid analogue, $\left[{ }^{18} \mathrm{~F}\right] 7$. The identity of the target compound was confirmed by co-injection with the cold standard 7 using an analytical HPLC system. Radiosynthesis and formulation of $\left[{ }^{18} \mathrm{~F}\right] 7$ took approximately $2 \mathrm{hr}$, with the yield ranging from $50-60 \%$, the specific activity was $>2,000 \mathrm{mCi} / \mu \mathrm{mol}$ (decay corrected to the end of synthesis), and the radiochemical and chemical purities were $>95 \%(\mathrm{n}=10)$. The radiosynthesis is straightforward and can be easily adapted to an automated synthesis module. Radiosynthesis of $\left[{ }^{11} \mathrm{C}\right]$ palmitate was performed as previously described (32).

\section{Biodistribution Studies}

The tissue distribution of $\left[{ }^{18} \mathrm{~F}\right] 7$ in adult male Sprague-Dawley rats is shown in Table 1. At 5 min post-i.v. injection, the uptake of $\left[{ }^{18} \mathrm{~F}\right] 7$ in the heart $(2.00 \pm 0.44 \% \mathrm{ID} / \mathrm{g})$ and liver $(2.71 \pm 0.37 \% \mathrm{ID} / \mathrm{g})$ was higher than any of the other tissues sampled. The ratio of activity in heart: non-target tissues was 2.55:1 for blood, and 8.3:1 for skeletal muscle. The brain had the lowest initial uptake of $\left[{ }^{18} \mathrm{~F}\right] 7,0.11 \pm 0.01 \% \mathrm{ID} / \mathrm{g}$; tracer uptake in fat activity was also very low, $0.14 \pm 0.02 \% \mathrm{ID} / \mathrm{g}$. $\left[{ }^{18} \mathrm{~F}\right] 7$ has a calculated $\log \mathrm{P}$ value of $5.56(\mathrm{ACD}, \mathrm{Log} \mathrm{D} /$ suite 7.0). Consequently, this high lipophilicity will make it difficult to passively cross the bloodbrain-barrier, which explains the low uptake of $\left[{ }^{18} \mathrm{~F}\right] 7$ in the brain. The 5 min uptake of $\left[{ }^{18} \mathrm{~F}\right] 7$ in liver was $2.71 \pm 0.37 \% \mathrm{ID} / \mathrm{g}$, the only organ with higher uptake than that seen in heart. By $30 \mathrm{~min}$ post injection, the uptake of $\left[{ }^{18} \mathrm{~F}\right] 7$ in heart had decreased to $35 \%$ of the 5 min activity and remained stable between 30 and $60 \mathrm{~min}(0.72 \pm 0.10$ and $0.86 \pm 0.28 \% \mathrm{ID} /$ $\mathrm{g}$, respectively). At $120 \mathrm{~min}$, the uptake of $\left[{ }^{18} \mathrm{~F}\right] 7$ in the heart remained $0.34 \pm 0.04 \% \mathrm{ID} / \mathrm{g}$, which was approximately 1.4 fold higher than that in blood $(0.26 \pm 0.06 \% \mathrm{ID} / \mathrm{g})$ at $120 \mathrm{~min}$. Between $30 \mathrm{~min}$ and $60 \mathrm{~min}$, activity in blood, liver and kidney continued to decrease, while activity levels in lung, heart, spleen muscle pancreas and brain remained fairly stable. The increase in mean uptake of $\left[{ }^{18} \mathrm{~F}\right] 7$ in lung and heart from 30 to 60 min was within experimental error and was not significant ( $\mathrm{P}$ values comparing the 30 and 60 min time points using the Students t-test were 0.56 for lung and 0.66 for heart). Bone and fat were taken only at the 5 and 60 min time points. Although the activity in fat increased $20 \%$ (from $0.14 \pm 0.02$ to $0.17 \pm 0.01 \% \mathrm{ID} / \mathrm{g}$, Students t-test $\mathrm{P}$ value $=0.04$ ) there was no significant accumulation of $\left[{ }^{18} \mathrm{~F}\right] 7$ activity in bone between 5 and $60 \mathrm{~min}$ (from $0.28 \pm 0.01$ to $0.33 \pm$ $0.06 \% \mathrm{ID} / \mathrm{g}$, Students t-test $\mathrm{P}$ value $=0.14$ ). These data indicate that there was no significant metabolic defluorination during the period of time needed for PET data acquisition.

\section{MicroPET Studies}

MicroPET imaging studies in adult male Sprague-Dawley rats $(\mathrm{N}=3)$ were also conducted in order to compare the myocardial uptake of $\left[{ }^{18} \mathrm{~F}\right] 7$ with that of $\left[{ }^{11} \mathrm{C}\right]$ palmitate.

Representative myocardial microPET images obtained from same rat are displayed in Figure $2 \mathrm{~A}$ when using $\left[{ }^{11} \mathrm{C}\right]$ palmitate and Figure $2 \mathrm{~B}$ when using $\left[{ }^{18} \mathrm{~F}\right] 7$. Images are displayed on 
the transaxial axis and represent data acquired $20-30$ min post-injection. $\left[{ }^{18} \mathrm{~F}\right] 7$ images displayed excellent quality and higher tracer activity than the corresponding $\left[{ }^{11} \mathrm{C}\right]$ palmitate images. PET images were consistent with the biodistribution data and showed no evidence of accumulation in bone. Because the biological half-life of $\left[{ }^{11} \mathrm{C}\right]$ palmitate in human heart is short, a tissue time-activity curve for $0-20$ min provides sufficient information for measuring the kinetics of fatty acid metabolism (33). To be consistent, Figure $2 \mathrm{C}$ and 2D display $0-20$ min tissue time-activity curves for both radiotracers. $\left[{ }^{18} \mathrm{~F}\right] 7$ exhibited significant tracer uptake in the heart and a rapid biphasic washout. However, some differences were noted when the data were compared with the time-active curves of $\left[{ }^{11} \mathrm{C}\right]$ palmitate. For example, $\left[{ }^{18} \mathrm{~F}\right] 7$ exhibited an early plateau followed by a slower early tracer clearance $(0.17 \pm 0.01$ vs. $0.30 \pm 0.02, \mathrm{P}<0.0001)$ and a significantly higher late clearance $(0.0030 \pm 0.0005$ vs. $0.0006 \pm 0.00013, \mathrm{P}<0.01)$. Studies to determine if the differences in washout kinetics of $\left[{ }^{18} \mathrm{~F}\right] 7$ versus $\left[{ }^{11} \mathrm{C}\right]$ palmitate reflect a difference in fatty acid metabolism or are due to the position of the radiolabel $\left(\mathrm{C}-1\right.$ position in $\left[{ }^{11} \mathrm{C}\right]$ palmitate vs. $p$-position of the benzene ring in $\left.\left[{ }^{18} \mathrm{~F}\right] 7\right)$ are currently ongoing in our group.

\section{CONCLUSION}

We have successfully synthesized the fatty acid analogue $\left[{ }^{18} \mathrm{~F}\right] 7$ with good yield, high radiochemical purity, and high specific activity. The initial biodistribution and microPET imaging studies of $\left[{ }^{18} \mathrm{~F}\right] 7$ in rats indicates that $\left[{ }^{18} \mathrm{~F}\right] 7$ displays a high uptake in heart and good contrast vs. blood and other tissues. The initial microPET studies of $\left[{ }^{18} \mathrm{~F}\right] 7$ in male Sprague-Dawley rats indicated that the tissue time-activity of $\left[{ }^{18} \mathrm{~F}\right] 7$ displays rapid biphasic washout kinetics similar to that of $\left[{ }^{11} \mathrm{C}\right]$ palmitate.

There is a compelling need for widely applicable radiotracer method that provides accurate and comprehensive measurements of myocardial fatty acid metabolism in humans. Current radiotracers are limited either by their lack of quantitative capability (e.g., $\left.\left[{ }^{1231}\right] \mathrm{BMIPP}\right)$, inability to track various aspects of fatty acid metabolism (e.g., $\left(\left[{ }^{18} \mathrm{~F}\right] \mathrm{FTHA}\right.$ or $\left.\left[{ }^{18} \mathrm{~F}\right] \mathrm{FTP}\right)$ or wide spread applicability (e.g., $\left[{ }^{11} \mathrm{C}\right]$ palmitate). The availability of $\left[{ }^{18} \mathrm{~F}\right] 7$ combined with appropriate image analysis tools should overcome these limits. The availability of these methods will facilitate the identification of relevant fatty acid metabolic biomarkers predictive of cardiac disease presence and/or progression and to evaluate specific therapeutic strategies. Once these data are obtained, the usefulness of this radiotracer technique in the clinical management of patients could be determined. Moreover, PET studies with $\left[{ }^{18} \mathrm{~F}\right] 7$ could be used to measure fatty acid metabolism in other organs such as skeletal muscle and liver. Thus, the impact on human health of an ${ }^{18} \mathrm{~F}$-labeled radiotracer for measuring fatty acid metabolism could be further expanded by enabling the study of other common diseases where alterations in cellular fatty acid metabolism are central to disease pathophysiology, such as insulin resistance syndrome and non-alcoholic fatty liver disease.

\section{Acknowledgments}

This research was supported by NIH grant HL69100 (RJG). The authors gratefully thank the staff of the Washington University Cyclotron Facility and the Washington University Small Animal Imaging Facility for their excellent technical assistance.

\section{ABBREVIATIONS}

$\begin{array}{ll}\text { BMIPP } & {\left[{ }^{123} \mathrm{I}\right] \beta \text {-methyl iodophenylpentadecanoic acid }} \\ {\left[{ }^{\mathbf{1 1}} \text { C }\right] \text { palmitate }} & {\left[{ }^{11} \mathrm{C}\right] \text { palmitic acid }} \\ {\left[{ }^{\mathbf{1 8}} \text { F }\right] \text { FCPHA }} & \text { trans-9(RS)-[ }\left[{ }^{18} \mathrm{~F}\right] \text { fluoro-3,4(RS,RS) methyleneheptadecanoic acid }\end{array}$




$\begin{array}{ll}{\left[{ }^{18} \text { F }\right] \text { FTHA }} & 14(\mathrm{R}, \mathrm{S})-\left[{ }^{18} \mathrm{~F}\right] \text { fluoro-6-thia-heptadecanoic acid } \\ {\left[{ }^{\mathbf{1 8}} \text { F }\right] \text { FTP }} & 16-\left[{ }^{18} \text { F }\right] \text { fluoro-4-thia-palmitate } \\ \text { HPLC } & \text { high-performance liquid chromatography } \\ \text { \% ID/g } & \text { percent injected dose per gram } \\ \text { IPPA } & \text { 15-(para-iodophenyl)-pentadecanoic acid } \\ \text { MP } & \text { Melting Point } \\ \text { ND } & \text { Not determined } \\ \text { PPAR } \alpha & \text { peroxisome proliferator-activated receptor alpha } \\ \text { PET } & \text { positron emission tomography } \\ \text { SPECT } & \text { single photon emission computed tomography } \\ \text { TLC } & \text { thin layer chromatography } \\ \text { TMS } & \text { tetramethylsilane }\end{array}$

\section{References}

(1). Yoshinaga K, Tamaki N. Imaging myocardial metabolism. Curr. Opin. Biotechnol. 2007; 18:5259. [PubMed: 17157495]

(2). Wisneski JA, Gertz EW, Neese RA, Mayr M. Myocardial metabolism of free fatty acids. Studies with ${ }^{14}$ C-labeled substrates in humans. J. Clin. Invest. 1987; 79:359-366. [PubMed: 3805273]

(3). Mathur A, Subramanian S, Mallia MB, Banerjee S, Samuel G, Sarma HD, Venkatesh M. Synthesis and bio-evaluation of a new fatty acid derivative for myocardial imaging. Bioorg. Med. Chem. 2008; 16:7927-7931. [PubMed: 18701306]

(4). Gropler RJ. PET Radiotracers of the Cardiovascular System. PET Clinics. 2009; 4:69-87.

(5). Shi CQ, Young LH, Daher E, DiBella EVR, Liu Y-H, Heller EN, Zoghbi S, Wackers FJT, Soufer $\mathrm{R}$, Sinusas AJ. Correlation of myocardial p- ${ }^{123}$ I-iodophenylpentadecanoic acid retention with ${ }^{18}$ F-FDG accumulation during experimental low-flow ischemia. J. Nucl. Med. 2002; 43:421431. [PubMed: 11884504]

(6). Behnam Azad B, Rota VA, Breadner D, Dhanvantari S, Luyt LG. Design, synthesis and in vitro characterization of Glucagon-Like Peptide-1 derivatives for pancreatic beta cell imaging by SPECT. Bioorg. Med. Chem. 2010; 18:1265-1272. [PubMed: 20056547]

(7). Peterson LR, Herrero P, Schechtman KB, Racette SB, Waggoner AD, Kisrieva-Ware Z, Dence C, Klein S, Marsala J, Meyer T, Gropler RJ. Effect of obesity and insulin resistance on myocardial substrate metabolism and efficiency in young women. Circulation. 2004; 109:2191-2196. [PubMed: 15123530]

(8). Peterson LR, Gropler RJ. Radionuclide imaging of myocardial metabolism. Circ. Cardiovasc. Imaging. 2010; 3:211-222. [PubMed: 20233863]

(9). Bashir A, Gropler RJ. Translation of myocardial metabolic imaging concepts into the clinics. Cardiol. Clin. 2009; 27:291-310. [PubMed: 19306771]

(10). Holness MJ, Samsuddin S, Sugden MC. The role of PPARs in modulating cardiac metabolism in diabetes. Pharmacol. Res. 2009; 60:185-194. [PubMed: 19376230]

(11). Burkart EM, Sambandam N, Han X, Gross RW, Courtois M, Gierasch CM, Shoghi K, Welch MJ, Kelly DP. Nuclear receptors PPAR $\beta / \delta$ and PPAR $\alpha$ direct distinct metabolic regulatory programs in the mouse heart. J. Clin. Invest. 2007; 117:3930-3939. [PubMed: 18037994]

(12). Shoghi KI, Gropler RJ, Sharp T, Herrero P, Fettig N, Su Y, Mitra MS, Kovacs A, Finck BN, Welch MJ. Time course of alterations in myocardial glucose utilization in the Zucker diabetic fatty rat with correlation to gene expression of glucose transporters: a small-animal PET investigation. J. Nucl. Med. 2008; 49:1320-1327. [PubMed: 18632819] 
(13). Otto CA, Brown LE, Wieland DM, Beierwaltes WH. Radioiodinated fatty acids for myocardial imagine: effects on chain length. J. Nucl. Med. 1981; 22:613-618. [PubMed: 7252566]

(14). Renstrom B, Rommelfanger S, Stone CK, DeGrado TR, Carlson KJ, Scarbrough E, Nickles RJ, Liedtke AJ, Holden JE. Comparison of Fatty Acid Tracers FTHA and BMIPP During Myocardial Ischemia and Hypoxia. J. Nucl. Med. 1998; 39:1684-1689. [PubMed: 9776269]

(15). Kudoh T, Tadamura E, Tamaki N, Hattori N, Inubushi M, Kubo S, Magata Y, Nishimura K, Matsuda K, Konishi J. Iodinated Free Fatty Acid and ${ }^{201}$ Tl Uptake in Chronically Hypoperfused Myocardium: Histologic Correlation Study. J. Nucl. Med. 2000; 41:293-296. [PubMed: 10688114]

(16). Eckelman W, Babich J. Synthesis and validation of fatty acid analogs radiolabeled by nonisotopic substitution. J. Nucl. Cardiol. 2007; 14:S100-S109. [PubMed: 17556177]

(17). Bergmann SR, Weinheimer CJ, Markham J, Herrero P. Quantitation of myocardial fatty acid metabolism using PET. J. Nucl. Med. 1996; 37:1723-1730. [PubMed: 8862319]

(18). Davila-Roman VG, Vedala G, Herrero P, de las Fuentes L, Rogers JG, Kelly DP, Gropler RJ. Altered myocardial fatty acid and glucose metabolism in idiopathic dilated cardiomyopathy. J. Am. Coll. Cardiol. 2002; 40:271-277. [PubMed: 12106931]

(19). Herrero P, Peterson LR, McGill JB, Matthew S, Lesniak D, Dence C, Gropler RJ. Increased myocardial fatty acid metabolism in patients with type 1 diabetes mellitus. J. Am. Coll. Cardiol. 2006; 47:598-604. [PubMed: 16458143]

(20). Stone CK, Pooley RA, DeGrado TR, Renstrom B, Nickles RJ, Nellis SH, Liedtke AJ, Holden JE. Myocardial uptake of the fatty acid analog 14-fluorine-18-fluoro-6- thia-heptadecanoic acid in comparison to beta-oxidation rates by tritiated palmitate. J. Nucl. Med. 1998; 39:1690-1696. [PubMed: 9776270]

(21). Takala TO, Nuutila P, Katoh C, Luotolahti M, Bergman J, Maki M, Oikonen V, Ruotsalainen U, Gronroos T, Haaparanta M, Kapanen J, Knuuti J. Myocardial blood flow, oxygen consumption, and fatty acid uptake in endurance athletes during insulin stimulation. Am. J. Physiol. Endocrinol. Metab. 1999; 277:E585-E590.

(22). Degrado TR, Wang S, Holden JE, Nickles RJ, Taylor M, Stone CK. Synthesis and preliminary evaluation of ${ }^{18}$ F-labeled 4-thia palmitate as a PET tracer of myocardial fatty acid oxidation. Nucl. Med. Biol. 2000; 27:221-231. [PubMed: 10832078]

(23). Taylor M, Wallhaus TR, Degrado TR, Russell DC, Stanko P, Nickles RJ, Stone CK. An evaluation of myocardial fatty acid and glucose uptake using PET with [ ${ }^{18}$ F]fluoro-6thiaheptadecanoic acid and $\left[{ }^{18} \mathrm{~F}\right] \mathrm{FDG}$ in patients with congestive heart failure. J. Nucl. Med. 2001; 42:55-62. [PubMed: 11197981]

(24). Wallhaus TR, Taylor M, DeGrado TR, Russell DC, Stanko P, Nickles RJ, Stone CK. Myocardial free fatty acid and glucose use after carvedilol treatment in patients with congestive heart failure. Circulation. 2001; 103:2441-2446. [PubMed: 11369683]

(25). Takala TO, Nuutila P, Pulkki K, Oikonen V, Gronroos T, Savunen T, Vahasilta T, Luotolahti M, Kallajoki M, Bergman J, Forsback S, Knuuti J. 14(R,S)-[ ${ }^{18}$ F]Fluoro-6-thia-heptadecanoic acid as a tracer of free fatty acid uptake and oxidation in myocardium and skeletal muscle. Eur. J. Nucl. Med. Mol. Imaging. 2002; 29:1617-1622. [PubMed: 12458396]

(26). Shoup TM, Elmaleh DR, Bonab AA, Fischman AJ. Evaluation of trans-9- ${ }^{18}$ F-fluoro-3,4methyleneheptadecanoic acid as a PET tracer for myocardial fatty acid imaging. J. Nucl. Med. 2005; 46:297-304. [PubMed: 15695790]

(27). DeGrado TR, Kitapci MT, Wang S, Ying J, Lopaschuk GD. Validation of ${ }^{18}$ F-fluoro-4-thiapalmitate as a PET probe for myocardial fatty acid oxidation: effects of hypoxia and composition of exogenous fatty acids. J. Nucl. Med. 2006; 47:173-181. [PubMed: 16391202]

(28). Kim DH, Choe YS, Choi JY, Choi Y, Lee KH, Kim BT. 17-[4-(2-[18 F]fluoroethyl)-1H-1,2,3triazol-1-yl]-6-thia-heptadecanoic acid: a potential radiotracer for the evaluation of myocardial fatty acid metabolism. Bioconjug. Chem. 2009; 20:1139-1145. [PubMed: 19530707]

(29). Welch MJ, Lewis JS, Kim J, Sharp TL, Dence CS, Gropler RJ, Herrero P. Assessment of myocardial metabolism in diabetic rats using small-animal PET: A feasibility study. J. Nucl. Med. 2006; 47:689-697. [PubMed: 16595504] 
(30). Shoghi KI, Gropler RJ, Sharp T, Herrero P, Fettig N, Su Y, Mitra MS, Kovacs A, Finck BN, Welch MJ. Time course of alterations in myocardial glucose utilization in the Zucker diabetic fatty rat with correlation to gene expression of glucose transporters: a small-animal PET investigation. J. Nucl. Med. 2008; 49:1320-1327. [PubMed: 18632819]

(31). Salomon A, Arad-Yellin R, Shanzer A, Karton A, Cahen D. Stable room-temperature molecular negative differential resistance based on molecule-electrode interface chemistry. J. Am. Chem. Soc. 2004; 126:11648-11657. [PubMed: 15366912]

(32). Welch MJ, Dence CS, Marshall DR, Kilbourn MR. Remote system for production of carbon-11 labeled palmitic acid. J. Label. Compd. Radiopharm. 1983; 20:1087-1095.

(33). Knuuti J, Takala TO, Nagren K, Sipila H, Turpeinen AK, Uusitupa MI, Nuutila P. Myocardial fatty acid oxidation in patients with impaired glucose tolerance. Diabetologia. 2001; 44:184-187. [PubMed: 11270674] 


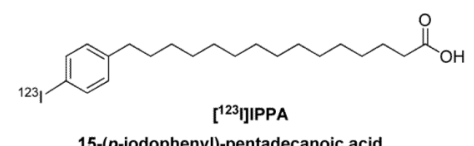

15-(p-iodophenyl)-pentadecanoic acid

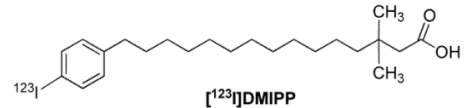

3,3-dimethyl-iodophenyl-pentadecanoic acid

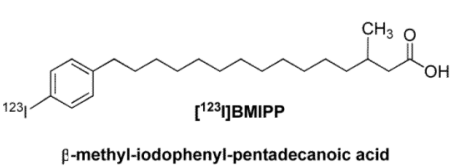

$\beta$-methyl-iodophenyl-pentadecanoic acid

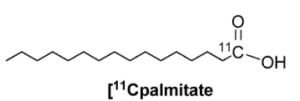

1-[11 C]palmitic acid

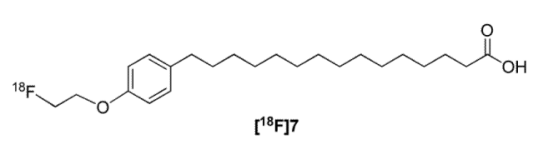

15-(4-(2-[ $\left.{ }^{18} \mathrm{~F}\right]$ fluoroethoxy $)$ phenyl)pentadecanoic acid

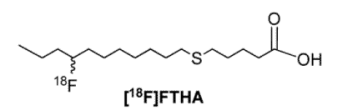

14(R,S)-[ [ $\left.{ }^{18} \mathrm{~F}\right]$ fluoro-6-thia-heptadecanoic acid

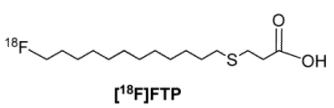

$16-\left[{ }^{18} \mathrm{~F}\right]$ fluoro-4-thia-palmitate

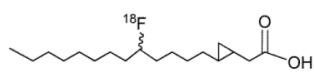

$\left[{ }^{18} \mathrm{~F}\right]$ FCPHA

trans-9(RS) $-\left[^{18} \mathrm{~F}\right]$ fluoro-3,4(RS,RS)methyleneheptadecanoic acid

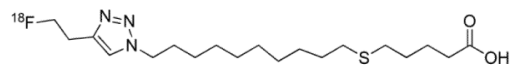

7-[4-(2-[18 $\mathrm{F}]$ fluoroethyl)-1H-1,2,3-triazol-1-yl]-6-thia-heptadecanoic acid

Figure 1.

Radiolabeled fatty acid analogs used in PET and SPECT imaging studies. 


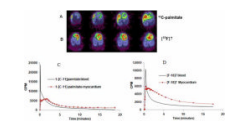

Figure 2.

MicroPET imaging studies of $\left[{ }^{11} \mathrm{C}\right]$ palmitate (Panel A) and $\left[{ }^{18} \mathrm{~F}\right] 7$ (Panel B) in male Sprague-Dawley rats. Images are displayed on the transaxial axis and represent data acquired $20-30 \mathrm{~min}$ post-injection of the radiotracer. $\left[{ }^{18} \mathrm{~F}\right] 7$ images display excellent quality and higher tracer accumulation than the $\left[{ }^{11} \mathrm{C}\right]$ palmitate images. Tissue-time-activity curve are shown in Panel $\mathrm{C}$ for $\left[{ }^{11} \mathrm{C}\right]$ palmitate and Panel D for $\left[{ }^{18} \mathrm{~F}\right] 7$. Both radiotracers display biphasic washout kinetics but some differences are noted. For example, when compared to $\left[{ }^{11} \mathrm{C}\right]$ palmitate, $\left[{ }^{18} \mathrm{~F}\right] 7$ exhibited an early plateau followed by a slower early tracer clearance $(0.17 \pm 0.01$ vs. $0.30 \pm 0.02, \mathrm{P}<0.0001)$; and a significantly higher late clearance $(0.0030 \pm$ 0.0005 vs. $0.0006 \pm 0.00013, \mathrm{P}<0.01)$. 


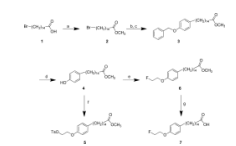

\section{Scheme 1.}

Synthesis of the precursor for radiolabeling and the HPLC standard.

Reagents and conditions: (a) trimethylsilyl diazomethane, THF, hexane, 2hr; (b) 4benzyloxyphenylboronic acid, $\mathrm{Pd}(\mathrm{OAc})_{2}$, [HP(t-Bu $\left.)_{2} \mathrm{Me}\right] \mathrm{BF}_{4}, \mathrm{KO}-\mathrm{t}-\mathrm{Bu}$, t-amyl alcohol, argon, RT; (c) 98\% sulfuric acid, methanol; (d) $\mathrm{Pd} / \mathrm{c}$, EtOAc, $\mathrm{H}_{2}$; (e) $\mathrm{BrCH}_{2} \mathrm{CH}_{2} \mathrm{~F}, \mathrm{~K}_{2} \mathrm{CO}_{3}$, acetone; (f) $\mathrm{TsOCH}_{2} \mathrm{CH}_{2} \mathrm{OTs}, \mathrm{K}_{2} \mathrm{CO}_{3}, \mathrm{CH}_{3} \mathrm{CN}$, reflux; g), $2 \mathrm{~N} \mathrm{NaOH}$, aqueous $\mathrm{MeOH}$. 


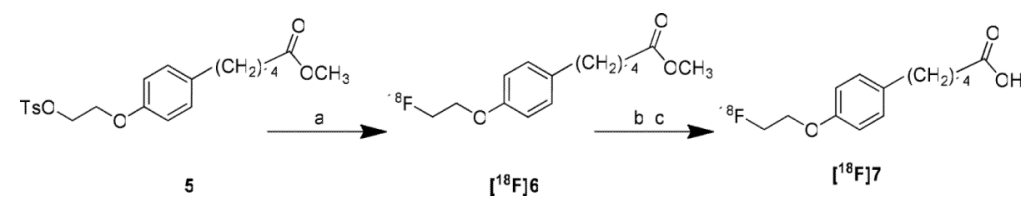

Scheme 2.

Radiosynthesis of $\left[{ }^{18} \mathrm{~F}\right] 7$.

Reagents and conditions (a) [ ${ }^{-8} \mathrm{~F}: \mathrm{F}-\mathrm{Kryptof} \times 222 \mathrm{~K}_{2} \mathrm{CO}_{3} \mathrm{CH}_{3} \mathrm{CN} 80^{\circ} \mathrm{C}$ (b) $2 \mathrm{~N} \mathrm{NaOH} /$ $\mathrm{MeOH} \mathrm{H}_{2} \mathrm{O}$ (c) $1 \mathrm{~N} \mathrm{HC}$ 
Table 1

Distribution of $\left[{ }^{18} \mathrm{~F}\right] 7$ in male Sprague-Dawley rats $(\% \mathrm{ID} / \mathrm{gram})^{a}$

\begin{tabular}{lcccc}
\hline & $\mathbf{5} \mathbf{~ m i n}$ & $\mathbf{3 0} \mathbf{~} \mathbf{m}$ & $\mathbf{6 0} \mathbf{~ m i n}$ & $\mathbf{1 2 0} \mathbf{~ m i n}$ \\
\hline blood & $0.76 \pm 0.05$ & $0.75 \pm 0.06$ & $0.56 \pm 0.06$ & $0.26 \pm 0.06$ \\
lung & $1.26 \pm 0.32$ & $0.87 \pm 0.06$ & $0.95 \pm 0.27$ & $0.52 \pm 0.06$ \\
liver & $2.71 \pm 0.37$ & $1.39 \pm 0.09$ & $0.81 \pm 0.10$ & $0.49 \pm 0.07$ \\
spleen & $0.94 \pm 0.05$ & $0.63 \pm 0.07$ & $0.57 \pm 0.11$ & $0.40 \pm 0.06$ \\
kidney & $1.30 \pm 0.09$ & $1.26 \pm 0.08$ & $1.02 \pm 0.15$ & $0.52 \pm 0.07$ \\
muscle & $0.23 \pm 0.03$ & $0.24 \pm 0.04$ & $0.21 \pm 0.02$ & $0.12 \pm 0.01$ \\
fat $b$ & $0.14 \pm 0.02$ & $\mathrm{ND}$ & $0.17 \pm 0.01$ & $\mathrm{ND}$ \\
heart & $2.00 \pm 0.44$ & $0.72 \pm 0.10$ & $0.86 \pm 0.28$ & $0.34 \pm 0.04$ \\
pancreas & $0.73 \pm 0.07$ & $0.50 \pm 0.03$ & $0.42 \pm 0.04$ & $0.28 \pm 0.02$ \\
brain & $0.11 \pm 0.01$ & $0.13 \pm 0.01$ & $0.10 \pm 0.01$ & $0.06 \pm 0.01$ \\
bone $b$ & $0.28 \pm 0.01$ & $\mathrm{ND}$ & $0.33 \pm 0.06$ & $\mathrm{ND}$ \\
\hline
\end{tabular}

${ }^{a}$ Data is shown as Mean \pm Std Dev.

${ }^{b}$ Results not determined (ND) for fat and bone at 30 and $60 \mathrm{~min}$. 